\title{
A Case Study of International - Friendly Campus in an EFL Environment
}

\author{
Chia Pei Wu (Corresponding author) \\ Dept. of Applied English, I-Shou University \\ No.1, Sec. 1, Syuecheng Rd., Dashu District, Kaohsiung City 84001,Taiwan, R.O.C \\ Tel: 886-7-6577711-5678Ｅ-mail: cpwu@isu.edu.tw
}

Cheng Hsu

Center for Teaching Excellence, National Pingtung University of Science and Technology

1, Shuefu Road, Neipu, Pingtung 91201, Taiwan, R.O.C.

Tel: 886-8-7703202-6295Ｅ-mail: hcpeter00@gmail.com

Received: February 9, 2015 Accepted: February 18, 2015 Published: February 18, 2015

doi:10.5296/ijele.v3i1.7120 URL: http://dx.doi.org/10.5296/ijele.v3i1.7120

\begin{abstract}
Due to the trend of internationalization in higher education, every university in Taiwan eagerly implements their facilities and employee trainings. By studying the learning experiences between the international students and the domestic students for achieving the internationalization of the campus, the government legislates for attracting more international students. Moreover, the universities should take actions to guarantee international students' adaptation of learning and living. Furthermore, both legislation and facilities can promote foreign students' motivation to study in Taiwan. Many international students do not know Chinese well, so universities have to offer efficient learning resources to decrease the difficulty of studying in Taiwan. The research methods comprised quantitative and qualitative methods to collect and analyze the data. The researchers collected seventy questionnaires, interviewed four students, and observed the classes to investigate the internationalization of the campus. This study investigated how the international learners' perceptions on Chinese learning, interaction with teachers and classmates, and English communication. The results revealed that the participants satisfied with Chinese learning, interaction with teachers and classmates, and English communication. However, the participants suggested that the administrative section of the campus lacks English proficiency. According to the interview, this study offered some suggestions for internationalization of the campus.
\end{abstract}

Keywords: friendly campus, international students, internationalization, EFL 


\section{Introduction}

Due to the international education and low birth rate, the government in Taiwan has realized that globalization has accelerated competition among universities around the world (Lo \&Weng, 2005; MOE, 2013a). To fascinate the international students, many schools devote to building international campus comprising language teaching and language communication. In addition, they have established the Office of International Affairs to deal with foreign students' affairs, and situational restaurants and classrooms to practice English. Many universities offer English-taught courses and programs for international and local students. A total of 41 universities had provided 193 programs delivered in English or other foreign language in 2011 (MOE, 2012). In the past five years, the number of international students who pursue an acadmic degree in Taiwan has risen 91 percent. According to the MOE (2012), there are over 40,843 international students from 148 countries who study in more than 23 diverse fields. Therefore, the government and universities promote internationalization projects and programs to attract more international students (Song \& Tai, 2007).

\section{Literature Review}

\subsection{Taiwan's Internationalization in the Higher Education Institutions}

Internationalization is regarded as the most important criterion when measuring the success of competitiveness of a university in Taiwan. Some scholars (Knight \& de Wit, 1997) defined the internationalization of higher education is that it is "the process of integrating an international/intercultural dimension into the teaching research and service functions of the institution." This definition only emphasizes the ability of an institution to introduce student body, the curriculum or faculty teaching and research activities. It ignored the process of integrating the institution into the global knowledge and learning network (Hawawini, 2011). Later, Hawawini proposed the broader definition: The internationalization of higher education institutions is the process of integrating the institution is the process of integrating the institution and its key stakeholders - its students, faculty, and staff - into a globalizing world. In 2006, Taiwan's Ministry of Education (MOE) published the document regarding White Paper on Higher Education Policy in which the low levels of internationalization, slow university developments and lack of financial support were the key factors for impeding higher education development. Taiwan MOE is starting to understand the importance the internationalization, many programs are offered for international students to study in Taiwan, for example the Taiwan Scholarship Program for degree students, the MOE Mandarin Enrichment Scholarship Program, and the MOE Scholarship for subsidizing international university students. Moreover, since 2009, and the Taiwan Hostfamily Program was inaugurated and 1,601 families have been trained all over Taiwan. Many volunteers across Taiwan opened their doors to international students from other countries (MOE, 2013b). The government promotes these programs to obtain an edge of the internationalization performance in the higher education institutions in Taiwan.

\subsection{Measurement of Internationalizing Institutions}

As for the measurement of internationalizing higher education, the Commission on International Education of the American Council on Education (1995) pointed out the importance of students developing the competence to function effectively in a global 
environment. This also referred to the need for state and local governments and the private sector to support higher education's efforts. Following an introductory section, the goals and benefits of international education are identified. The following 10 ground rules for internationalizing institutions: (1) require that all students demonstrate competence in at least one foreign language; (2) encourage understanding of at least one other culture; (3) increase understanding of global systems; (4) redesign curricula to reflect the need for international understanding; (5) expand study abroad and internship opportunities for all students; (6) focus on faculty development and rewards; (7) examine the organizational needs of international education; (8) build consortia to enhance capabilities; (9) cooperate with institutions in other countries, and (10) work with local schools and communities. These rules may not all apply to English as foreign language (EFL) settings such as Taiwan. Some scholars proposed criteria of examining internationalization efforts of higher education institutions. Chin and Ching (2009) proposed twelve internationalization indicators. These indicators are: institutional commitments, strategic planning, funding, institutional policy and guidelines, organizational infrastructure and resources, academic offerings and curriculum, performance evaluation and accountability, internet presence, faculty and faculty development, international students and scholars, study abroad, and campus life. Chin and Ching's study first attempted to try to establish indicators to measure Taiwan higher education institutions internationalization. Chin, Wu and Ching's study (2012) employed these internationalization indicators to conduct the research that Taiwan's internationalization performance in high education institutions is fairly (52\%), especially in the curriculum design should be reconsidered for local and international students and make plans to expand foreign branches outside Taiwan.

\subsection{Research Questions}

The goal of the study was to investigate the indicators of Taiwan's higher education internationalization. The following were the research questions:

1. What were the strategies that a higher education institution may use in order to achieve internationalization?

2. How friendly were the facilities that were employed by international students?

\section{Methodology}

Quantitative and qualitative methods were conducted in this research. This mixed method study was systematically collected data and discussed the international students' insights. As for the quantitative research, the study was investigated the descriptive research. The descriptive research is related to relationships or conditions that exist, practices that beliefs, points of views, or attributes that are held, processes that are ongoing, effects that are being felt (Best, 1970). In addition, individual interviews were used to gather data, which were then transcribed and analyzed. The researcher would note patterns and themes, clustering items into categories, building logical chains of evidence through noting causality and making conceptual coherence (Mils \& Huberman, 1994).

\subsection{Participants and Data Collection}

Participants were from a university in south Taiwan, I-Shou University. This comprehensive university provided the resources to assist international students in their learning environment. 
Chinese was the primary language for communication, but the school creates English-speaking environment recently. The average age was 21 with the majority being females. Most of them had English learning experience for more than 7 years. Seventy participants were from Malaysia (32) and Vietnam (38). They major in mass communication, business or English.

Researchers would conduct the class observation and get the consent forms from the participants to complete the questionnaire. Besides, among those seventy students, researchers got the permission from them and selected four learners to participate in the interview.

The data collected from different sources (questionnaires, interview responses, and researchers' observation). The researcher would code the data and triangulate the data to enhance reliability and validity. This mixed method can collect the data from a crowd of participants in a short period of time to analyze the existing problems ( $\mathrm{Lu}, 2004)$. Before distributing the questionnaire, the researchers conduct the pilot test and make some revisions for the questionnaire and interview questions.

\subsection{Procedure}

In 2013 March, the procedure was employed two stages. Firstly, the international students were asked to complete the questionnaires in Chinese language program. Secondly, researchers obtained the convenient samples for four participants involving Vietnamese and Malaysian to conduct the interview. During the interview, the language was conducted in English for reducing the fears and anxiety, and they could express more precisely. The average age was 21 with the majority being females. Most of them had learned English for more than 7 years.

The questions of the questionnaire include semi-structured interview; hence, researchers sketched the interview and examine in depth based on the interviewees' answers. Moreover, researcher would provide the interview questions for the interviewees previously to response exactly. Furthermore, the interview language would use the interviewees' familiar language, which was English to express accurately. The interview questions comprised with learning and language experience and the learning experience, the interaction with teachers and fellows, and the assistances of the library and the administrative sections.

Additionally, the required time for the interview was about fifteen minutes. The interview capitalized on the learning experience and language practice of the application to the library and the administrative sections. Tape-recording was employed to collect the original data of the interview, and transcription was utilized to get the more in-depth information for analysis of the interview.

\subsection{Instrument}

The major instruments employed by this study were questionnaires about internationalization, a semi-structured interview and classroom observations. This questionnaire was adapted from Wu's study (2006) and Chin and Ching (2009) regarding the overseas Chinese college students' campus experience and academic achievements and Han's study about a study on international students' learning experiences and the process of academic adjustment in Taiwan (Han, 2008). 
The interview centered on understanding thinking processes and the interpretation of actions of the interviewee, and its advantage was that through the specific description, readers could appreciate interviewees' thinking and experience (Fan, 2004). In addition, National Taiwan Normal University (2013) indicated that the observation was also the participative observation. Normally, a researcher was encompassed by the participants, observing directly and recording on the spot. The researchers would come to classrooms to observe the interaction between teachers and students in Chinese program every week and write notes before getting the permissions.

\section{Findings and Discussions}

After the questionnaire and observation were collected and coded, the study conducted interviews to further determine their reflection about university internationalization. The study's findings are outlined and discussed on the basis of the proposed questions. The data are presented to demonstrate a comprehensive view in this study.

4.1 What are the strategies of a higher education institution used in order to achieve internationalization?

The finding of quantitative and qualitative research would be conducted in this question. This questionnaire would be divided into five sections: learning experience, the interaction with teacher, the interaction with classmates, and the assistances of the library and the administrative sections.

The results from the questionnaire showed clearly that most of the students think that international students would turn to teachers or teaching assistants to overcome schoolwork problems , $(M)=3.04$, but the teachers instructed in English was the lowest $(M=2.9)$. Table 1 shows the participants' learning experience in Taiwan. Particularly, only the courses in the department of International Business Administration, International Finance, International Tourism and Hospitality, and Entertainment Management were instructed in English in I-Shou University. Besides, initiating in 2013, school of medical college for international students started instructing in English (Central News Agency, 2013). Therefore, teachers instruct in English was the lowest $(M=2.9)$

Table 1. Learning Experience

\begin{tabular}{llc}
\hline \multicolumn{1}{c}{$(\mathrm{n}=70)$} & $\mathrm{M}$ & $\begin{array}{c}\text { the highest and lowest } \\
\text { values }\end{array}$ \\
\hline Topics & 3 & highest \\
\hline I attend the discussion and express my thoughts in class. & 3.04 & \\
$\begin{array}{l}\text { I turn to teachers or classmates to overcome my schoolwork } \\
\text { problems. }\end{array}$ & 2.93 \\
I discuss with teachers about the course problems actively. & 2.9 & lowest \\
In class, teachers instruct in English. & 2.97 & \\
Average &
\end{tabular}


Apart from the English teaching, the majority of students agreed that they would turn to teachers or companions to overcome schoolwork problems $(M=3.04)$. For instance, Participant \#02 said that "When I have some problems about the teaching contents, I would ask Taiwanese students." The quantitative and qualitative results indicated that students would turn to teachers or schoolmates to solve schoolwork problems.

Findings from the interaction with teachers indicated that most of the students interacted well with the teachers $(M=3.09)$, but the majority disagreed that they would share their private problems with the teacher $(M=2.33)$. Table 2 shows the interaction between teachers and students. According to the table, the majority of students agreed that they interacted well with the teacher $(M=3.09)$.

However, participants barely mentioned that they would share their non-academic problems with the teachers in the interview. Researchers conjectured that international students seldom discussed the non-academic questions. The topics of conversation were limited to the schoolwork. As a result, learners seldom share their non-academic problems with the teachers.

Table 2. Interaction with Teacher

\begin{tabular}{lll}
\hline & $M \quad(n=70)$ & the highest and lowest values \\
\hline Topics & 2.89 \\
\hline I ask the teacher questions about my studies actively after class. & 2.33 \\
I share my private problems with the teacher. & 3.04 \\
The teacher cares my learning experience actively. & 2.97 \\
The teacher assists my study actively after class. & 3.09 \\
I interact well with the teacher. & 2.69 \\
I participate in speeches at school. & 2.83 \\
Average &
\end{tabular}

The results from quantitative research demonstrated that when students encountered some difficulties, schoolmates helped them actively $(M=3.11)$. Nevertheless, subjects disagreed that they had difficulty in getting along with classmates $(M=2.16)$ which represented that participants had no difficulty in making friends with fellows. Table 3 shows that the participants with the classmates. Based on the table, companions would help foreign learners actively $(M=3.11)$. For instance, Participant \#01 indicated that "Taiwanese students were friendly, and they would help me."In the view of class observation, when students puzzled at the task, fellows would assist them in English. Additionally, after the class, learners would 
chat and exchange information in English. Consequently, researchers considered that the classmates are willing to communicate with these international students in English.

Table 3. Interaction with classmates

\begin{tabular}{|c|c|c|}
\hline \multicolumn{3}{|c|}{$(\mathrm{n}=70)$} \\
\hline Topics & M & $\begin{array}{l}\text { the highest and lowest } \\
\text { values }\end{array}$ \\
\hline
\end{tabular}

I discuss and do the report with my classmates.

I attend the class activity (e.g. class meeting or picnic).

I have difficulty in getting along with classmates.

I have a good time having a meal with classmates.

I get along with classmates.

When I encounter some difficulties, classmates help me actively.

Classmates turn to me when they have problems.

I make friends with the local (Taiwanese) students.

It is no problem to communicate with the classmates.

It is no problem to communicate with Taiwanese students.

I discuss with Taiwanese students by speaking English.

I get along with the Taiwanese roommates.

When I encounter some problems, I turn to English-speaking or the same language students only.

Average
$2.16 \quad$ lowest

3.01

3.01

$3.11 \quad$ highest

3.04

2.83

The data from quantitative research agreed that lots of the participants agreed that the facilities of the library were good $(M=3)$, yet many subjects disagreed that the resource system of the library assisted them well $(M=2.94)$. Table 4 shows that the participants' opinions towards assistance of library services. Particiant\#2 expressed that two libraries were laden with resources, for instance, e-book and digital multimedia data. The resources refer to the availability of an internationalization support system. This includes physical facilities, such as office spaces, communication and technological resources. As Participant \#01 pointed 
out that "the library is abundant in the books and the resources." In addition, Participant \#03 expressed that "the library has a lot of books." Also, Participant \#02 indicated that "the seats are big and convenient for studying, and the computers can be borrowed to use." Similarly, according to Participant \#04, "the library is very big with a lot of English books. The library offers the enough books, so we can get enough information." Even though learners thought that the facilities of the library were professional, most interviewees did not have the experience to utilize the resource system of the library. This explained that the score ranked in this category was the lowest.

Table 4. Assistance of Library service

\begin{tabular}{|c|c|c|}
\hline$(\mathrm{n}=70)$ & & \\
\hline Topics & M & $\begin{array}{c}\text { the highest and lowest } \\
\text { values }\end{array}$ \\
\hline The resource system of the library assists me well. & 2.94 & lowest \\
\hline The staff of the library assists me well. & 2.97 & \\
\hline It is no problem to communicate with librarians. & 2.96 & \\
\hline $\begin{array}{l}\text { The facilities of the library are good (e.g. computer and printer, } \\
\text { etc.). }\end{array}$ & 3 & highest \\
\hline Average & 2.97 & \\
\hline
\end{tabular}

Results from quantitative research indicated that most of the students considered that the assistants of their departments could help them to solve the problems when taking courses $(M=3.03)$, yet the majority disagreed that the courses registration system and its illustration were clear $(M=2.74)$. Table 5 shows that the participants' opinions towards assistance of administrative staff. On the basis of the assistants of the department, Participant \#03 expressed that "the assistants of the department, they are very active to help and they really care about you." Furthermore, Participant \#04 mentioned that "if we have any problems, we could ask the assistants of the department." Based on the statistics and excerpts above, the results revealed that the assistants of the department could help learners to solve the problems when taking courses. Nevertheless, international students considered that the course registration system and its illustration needs to be reinforced. The presence of professional staff and personnel responsible for international students' need is seen as highly crucial in achieving internationalization (Chin \& Ching, 2009).

Table 5. Assistance of Administrative Staff

$(n=70)$

\begin{tabular}{ll}
\hline Topics & $M \quad$ the highest and \\
\hline
\end{tabular}


lowest values

The administrative sections provide English service.

English signs on the campus help me effectively.

When I have administrative problems, they can help me. (e.g. register, 2.84 accommodation, and taking courses)

The courses registration system and its illustration are clear.

$2.74 \quad$ lowest

The design of the school website is environment-friendly and clear.

The school website (office of student affairs) provides understandable language

(English or my native language) to understand the contents and usage.

The website of my department provides understandable language (English or

my native language) to understand the contents and usage.

It is no problem to communicate with the assistants of my department.

The assistants of my department can help me to solve the problems when 3 taking courses.

The assistants of my department can solve my problems during the semester.

\subsection{How friendly are the facilities that are employed by international students?}

According to the interviewees' responses, the announcements of the dormitory were bulletined in Chinese, and it bothered the international learners. Participant \#03 said, "the dormitory offers the paper to sign up or even we are the international students, they still write in Chinese." Besides, the school website and the website of department contained the English version, but it was scant of the information and did not update promptly. Participant \#03 mentioned that "the school website is better if school can change the Chinese into English. There are many parts they lack of much English information, I mean they do not update in time." Also, Participant \#04 thought that "if their poster and the information in English are much better for the international students." Additionally, students thought that the school website and the website of department were complicated. Participant \#03 considered that "I think it should be design more clear because it takes time. For our school website, it looks too 
simple and not professional enough. The website of our department is the same as our school website." Similarly, according to Participant \#04, "about the school website, it also has the Chinese stuff, but we cannot read. In Vietnamese version, the information is quite limited. The information is not enough for the international students'learning needs, so it's not easy for us to use the school website."

Also, the e-mail system for international students is only in Chinese and English that led to the inconvenience. Participant \#03 expressed that "the school informed the international students in Chinese, and it would be difficult for them to catch up the information." Equally, Participant \#04 indicated that "the assistant of the department, their post of the department is in Chinese, and we cannot read Chinese. We get the email and the information only in Chinese, so we cannot know about the activities and information of the school." Generally, the procedures of the administrative section were excessively complex. Participant \#03 considered that "many times, we go to administrative building to do some administrative task. I think it takes time and go through too many procedures."

In the light of the international-friendly campus, some participants reported that English speaking proficiency for assistants of the International College and administrators in the office of the international affairs was not capable, the major administrators, assistants, and dormitory superintendents may have difficulty in communicating with international students and solve the problems. Participant \#03 mentioned that "the assistants' English should be improved, and the same as the dormitory's." Additionally, Participant \#04 indicated that "about the administrative section, I go there to do some paper work. The paper used in the administrative section is in Chinese."

Overall, after conducting the questionnaire, observations and interview, this study would discuss seven ground rules for internationalizing institutions of higher education based on the American Council on Education (1995):

(1) All graduates demonstrate competence in at least one foreign language. Indeed, I-Shou University asks students to take English proficiency tests to meet the graduation requirement. The international had frequent problems in understanding and expression when they communicate with staff, but not the classmates.

(2) Students increase understanding of global systems. The General Education in I-Shou University offers the courses of international relations, international business, global climate change, international security issue, and so forth.

(3) Schools should reform curricula to reflect the need for international students. The courses of Department of International Business Administration, International Finance, International Tourism and Hospitality, and Entertainment Management were instructed in English in I-Shou University. Also, School of Medical for international students was instructed in English in class (Central News Agency, 2013).

(4) Schools expand study abroad and internship opportunities for all students. I-Shou University provides scholarships to encourage students to study abroad.

(5) Schools examine the organizational needs of international education. The director of the 
office of international affairs in I-Shou University mentioned that the school makes efforts on internationalization for many years. For example, the school would arrange language partners for international students and help promote inter-cultural activities.

(6) Schools cooperate with institutions in other countries. I-Shou University claims that the school provides study abroad programs in 92 Chinese universities and 347 sister schools in Asia, Europe, America, and Australia (Central News Agency, 2013). These programs include Founding Programs for University Students' Short-term Study or Internships Overseas, or Taiwan Government Scholarships for Overseas Study. Furthermore, it offers joint (dual) degree programs and student exchange programs between partner universities (Central News Agency, 2013)

(7) Schools work with local schools and communities. To achieve the internationalization, Ministry of Education (MOE) has promoted the programs of recruiting international students and established the international campus. In 2013, National Cheng Kung University, Taipei Medical University, Southern Taiwan University of Science and Technology, and I-Shou University won the outstanding universities of the international students' counseling service (Central News Agency, 2013). International students in I-Shou University have priorities of applying dormitories and the school establishes International Student Lounge to create more inter-cultural exchange opportunities.

\section{Conclusion}

Seventy international students from I-Shou University were selected to complete the questionnaire. Besides, among those seventy learners, two students from Vietnam and two females from Malaysia were selected as the interviewees. In addition, the study would use convenient sampling because the researchers can reach them in our department. The primary aim of this research is to discuss the university internationalization in terms of their learning experience in Taiwan, the interaction with teachers and fellows, and the assistances of the library and the administrative sections.

The findings of learning experience in Taiwan revealed that the participants would consult teachers or classmates to overcome schoolwork problems, but most teachers instructed in Chinese for only some international departments taught in English; therefore, the difficulties of getting proper consults existed. Most of the international students overcome those difficulties and interacted well with instructors and schoolmates. Additionally, according to the class observation, international students would chat and exchange information in English with their teachers and schoolfellows. Therefore, improving the curriculum and the availability of English course programs are also seen an objective of internationalization.

Regarding administrative sections, participants suggested that the announcements of the dormitory and the e-mail to international students should be composed in English. Additionally, the information in school website and the websites of department could be simplified, and the English version could be updated in time. Furthermore, the procedures of the paper work in the administrative section could be simplified. Also, the courses registration system was not clear; however, the assistants of the department could solve the problems of taking courses. Concerning the administrative problems, most of administrators, 
assistants, and dormitory superintendents could not communicate with international students and solve the problems in English. Indeed, limited English communication proficiency for some administrative staff and English friendly environment in I-Shou University need to be improved.

To summarize, Taiwanese government focuses much of the internationalization efforts on many study abroad programs and international collaboration organizations and projects. However, overall internationalization performance in Taiwan has a long way to go. The participants of this study are conducted only 70 international students from Malaysia and Vietnam in one higher institution in Taiwan. They share similar educational backgrounds. While this study is still in its preliminary stage, further studies on university internationalization should conduct participants' various academic backgrounds. In addition, fellow scholars would consider using diverse internationalization scales to explore in-depth insights from teachers, international and local students and administrative staff.

\section{References}

Altbach, P. G. (1991). Impact and adjustment: Foreign students in comparative perspective. Higher Education 21, 305-323. http://dx.doi.org/10.1007/BF00132723

American Council on Education. (1995). Educating Americans for a World in Flux: Ten Ground Rules for Internationalizing Higher Education. American Council on Education, Washington, D.C.

Best, J. W. (1970). Research in education. Englewood Cliffs, NJ: Prentice Hall.

Central News Agency. (2013). The Internationalization of I-Shou University. Taipei. Retrieved March 10, 2014, from database on Central News Agency: http://www.cna.com.tw/postwrite/Detail/127858.aspx\#.UzLIE6iSyE4

Chin, J. M. C., \& Ching, G. S. (2009). Trends and Indicators of Taiwan's Higher Education Internationalization. Asia-Pacific Education Researcher, 18(2). http://dx.doi.org/10.3860/taper.v18i2.1322

Fan, L. C. (2004). Qualitative Research. Taipei: Psychological Publishing Corporation.

Galloway, A. (2010). Communicative language teaching: An introduction and sample activities. Retrieved March 10, 2014, from http://www.cal.org/resources/digest/gallow01.html

Han, K. L. (2008). A Study on International Students' Learning Experiences and the Process of Academic Adjustment in Taiwan-The International Undergraduate Students of National Taiwan Normal University as an Example. Unpublished doctoral dissertation, National Taiwan Normal University, Taipei

Hawawini, Gabriel, The Internationalization of Higher Education Institutions: A Critical Review and a Radical Proposal (November 4, 2011). INSEAD Working Paper No. 2011/112/FIN. Available at SSRN: http://ssrn.com/abstract=1954697, http://dx.doi.org/10.2139/ssrn.1954697

Knight, Jane \& Hans de Wit (1997). Internationalization of higher education in Asia Pacific 
countries. Amsterdam: European Association for International Education Publications.

Liao, B. S. (2006). Self-examination of CLT. Retrieved March 10, 2014, from http://blog.udn.com/trjason/212005

Lu, C. Y. (2004). Quantitative Research. Education Bureau Penghu County Government

Lo, Y.W., \& Weng, F.Y. (2005). Taiwan's responses to globalization: Internationalization of higher education. In K.H. Mok \& R. James (Eds), Globalization and higher education in East Asia (pp. 137-156). Sinagapore: Marshall Cavendish Academic.

Ministry of Education. (2012).Department of International and Cross-strait Education. $\begin{array}{llll}\text { Retrieved } & \text { December } & 2013, & \text { from }\end{array}$ http://www.edu.tw/Default.aspx?WID=409cab38-69fe-4a61-ad3a-5d32a88deb5d

Ministry of Education (2013a). UMAP Taiwan Exchange Student Scholarship. Retrieved November 23, 2014, from http://www.edu.tw/news1/detail.aspx?Node=1088\&Page=21850\&wid=6635a4e8-f0de-4957aa3e-c3b15c6e6ead\&Index $=1$

Ministry of Education (2013b). The 2014 Ministry of Education Top 100 University Scholarship Program. Retrieved December 3, 2014, from http://english.moe.gov.tw/ct.asp?xItem $=15824 \& c t N o d e=11414 \& m p=1$

Mils, M., Huberman, M. (1994). Qualitative data analysis . Beverly Hills, CA: Sage.

National Taiwan Normal University. (2013). Observation. Taipei. Retrieved March 10, 2014, from database on National Taiwan Normal University: http://www.proera.com.tw/upload/ckfinder/827_files/20131006_030144.pdf

Panitz, T. (1999). Collaborative versus cooperative learning- a comparison of the two concepts which will help us understand the underlying nature of interactive learning. Retrieved March 10, 2014, from http://home.capecod.net/ tpanitz/tedsarticles/coopdefinition.htm

Shih, H. L. (2006). Investigation of international students' social support and life adjustment in Taiwan-a case study of Ming Chuan University Taoyuan Campus' international students. Unpublished doctoral dissertation, Ming Chuan University, Taoyuan.

Silverman, D. (2005). Doing qualitative research. Thousand Oaks, CA:Sage.

Song, M.M., \& Tai, H.H. (2007). Taiwan's responses to globalization: Internationalization and questing for world class. Asia Pacific Journal of Education, 27(3), 323-340. http://dx.doi.org/10.1080/02188790701594067

Wu, Y. L. (2006). Overseas Chinese College Students' Campus Experience and Academic Achievements. Unpublished doctoral dissertation, National Taiwan Normal University, Taipei. 


\section{Ml Macrothink \\ International Journal of English Language Education \\ ISSN $2325-0887$ 2015, Vol. 3, No. 1}

\section{Copyright Disclaimer}

Copyright for this article is retained by the author(s), with first publication rights granted to the journal.

This is an open-access article distributed under the terms and conditions of the Creative Commons Attribution license (http://creativecommons.org/licenses/by/3.0/). 